\title{
Types of dry-season stream pools: environmental drivers and fish assemblages
}

\author{
Maria Ilhéu , Janine da Silva , Manuela Morais , Paula Matono \& João Manuel \\ Bernardo
}

To cite this article: Maria llhéu, Janine da Silva, Manuela Morais, Paula Matono \& João Manuel Bernardo (2020) Types of dry-season stream pools: environmental drivers and fish assemblages, Inland Waters, 10:4, 516-528, DOI: 10.1080/20442041.2020.1843931

To link to this article: https://doi.org/10.1080/20442041.2020.1843931

曲 Published online: 11 Dec 2020.

Submit your article to this journal $\pi$

山 Article views: 48

Q View related articles $\sqsubset$

View Crossmark data ־ 


\title{
Types of dry-season stream pools: environmental drivers and fish assemblages
}

\author{
Maria Ilhéu, ${ }^{\mathrm{a}, \mathrm{b}}$ Janine da Silva, ${ }^{\mathrm{a}}$ Manuela Morais, ${ }^{c}$ Paula Matono, ${ }^{\mathrm{b}}$ and João Manuel Bernardo ${ }^{\mathrm{a}}$ \\ ${ }^{a}$ Department of Landscape, Environment and Planning, University of Évora, Évora, Portugal; ${ }^{b}$ MED Mediterranean Institute for Agriculture, \\ Environment and Development, Universidade de Évora, Évora, Portugal; 'Department of Biology, University of Évora, Évora, Portugal
}

\begin{abstract}
Many river networks in southern Europe are intermittent. In summer, the surface flow is zero and many streams become isolated pools. In this study, 128 dry season pools were studied covering first- to fourth-order streams on the Degebe River network (south Portugal). The aim of the study was to identify pool types based on environmental drivers and conditions and fish assemblages. In summer, dry streambed area exceeded $50 \%$ in all reaches and $95 \%$ in headwater sections. The pool features were primarily shaped by their location in the river network, which determined the pool morphology and the structure of fish assemblages. Pool sizes increased from upstream to downstream, as did species richness and diversity. Pools in upstream reaches were dominated by small native fishes while the larger-sized individuals tended to occupy deeper, larger, and more persistent pools. Smaller pools in downstream reaches were dominated by non-native species, which may be related to habitat preferences and minimization of negative interactions between native and non-native species. Because dry season pools represent key habitats in intermittent streams, conservation programs should be designed to reduce human pressures and improve hydromorphological heterogeneity and water quality, taking into account the natural patterns of pool types at regional and local scales.
\end{abstract}

ARTICLE HISTORY

Received 1 March 2020

Accepted 27 October 2020

\section{KEYWORDS}

freshwater fish;

Mediterranean climate

streams; Portugal; summer

stream pools; temporary

rivers

\section{Introduction}

Intermittent rivers and streams are dynamic ecosystems shaped by alternating wet and dry periods over annual cycles, which promote spatial complexity and control biodiversity and biogeochemical processes (e.g., Arthington et al. 2014, Datry et al. 2016). The cycles of expansion and contraction, driven by surface discharge and groundwater level variations, create high heterogeneity in the habitat patchiness across these river networks (e.g., Lake 2003, Larned et al. 2010, Godsey and Kirchner 2014). These cycles determine a seasonal shift between lotic and lentic habitats. During flow recession, lotic habitats contract, reducing depth and width. As flow ceases and contraction continues, streams become a longitudinal succession of disconnected pools (e.g., Matthews and Marsh-Matthews 2003, Lake 2011).

Dry season stream pools are temporary habitats that represent primary refugia for the stream biota and are a crucial source of colonists upon flow resumption (e.g., Humphries and Baldwin 2003, Magoulick and Kobza 2003). The natural features of these summer pools, including their environmental conditions to support the aquatic communities, are expected to result from a complex interplay between the riverine spatial context (hydro-geomorphometric) and the magnitude, frequency, and duration of the natural disturbance associated with the temporal flow variability (e.g., Buffington et al. 2002). Pools are patches where dispersal dynamics (during the wet season) and environmental selection (dry season) act, shaping local assemblages.

The Mediterranean region is a global biodiversity hot spot, supporting an important freshwater fish biodiversity with a high number of endemic species (Reyjold et al. 2007). In this region, many rivers are intermittent and their networks are complex, comprising a high number of river basins with different environmental conditions where populations are strongly isolated (e.g., Smith and Darwall 2006, Datry et al. 2017). The native fish fauna has evolved in a changeable and sometimes extreme environment, tending to show high spatial-temporal variability on their composition and structure (e.g., Magoulick 2000). The species capacity to cope with the persistence of the refugia during the dry period (Capone and Kushlan 1991, Schwartz and Jenkins 2000, Bernardo et al. 2003, Matthews and Marsh-Matthews 2003), the physical-chemical constraints (Schaefer et al. 2003, Ilhéu 2004, Dekar and Magoulick 2007), and the biotic interactions (Closs

CONTACT Maria Ilhéu milheu@uevora.pt $⿴$ Department of Landscape, Environment and Planning, University of Évora, Rua Romão Ramalho 59, 7000-671 Évora, Portugal; MED Mediterranean Institute for Agriculture, Environment and Development, Universidade de Évora, Pólo da Mitra, Apartado 94, 7006-554 Évora, Portugal

(c) 2020 International Society of Limnology (SIL) 
and Lake 1996, Magoulick 2000) determine fish composition and dynamics in intermittent streams. Summer pools can harbor high fish densities that increase the negative biotic interactions (Lake 2003, White et al. 2016). Consequently, fish assemblages undergo shifts in taxonomic composition (Bêche et al. 2006), and are subjected to mass mortality events (Tramer 1977, Mundahl 1990), and local eradications (Matthews and Marsh-Matthews 2003).

Considering the spatiotemporal dynamics of intermittent streams, both local and regional factors can simultaneously and interactively influence the composition and structure of fish assemblages (Angermeier and Winston 1998, Magoulick 2000, Pires et al. 2014). During the dry season, fish assemblages can be perceived as metacommunities, consisting in distinct units separated by space and shaped by local processes, including species interactions, local environmental conditions, and regional processes related primarily to the dispersal abilities of species (Leibold et al. 2004). The dispersal process allows the connection of local communities during the stream expansion phase but also plays a key role in species sorting during the contraction phase, when flow recedes and pools become isolated (Ilhéu 2004).

Despite their conservation value, many habitats and fish species in intermittent streams are threatened (Smith and Darwall 2006). Under the pressure of climate change and increasing human-induced disturbance, many streams and rivers are becoming more intermittent (Vörösmarty et al. 2010, Döll and Schmied 2012), and their environmental conditions are expected to deteriorate mainly during the dry season (Matono et al. 2014, 2019). River scientists are increasingly interested in intermittent rivers and streams (Larned et al. 2010, Datry et al. 2014, Leigh et al. 2015), but the number of studies addressing the relationship between summer pool features (morphometrical and physicalchemical) and fish assemblages considering different spatial scales is still limited (but see Magoulick and Kobza 2003). A comprehensive understanding of the local and regional factors that determine the pattern of pool types in the river networks is crucial to support conservation actions that ensure habitat integrity and the persistence of communities.

Our aim was to contribute to the understanding of dry season pools patterns-physical, chemical, and biological (fish assemblages) - along the river network, providing information for conservation programs, namely by identifying pool types. This classification is useful for both research and management professionals, allowing them to establish monitoring programs and assess cumulative impacts of human activities on streams and their biota (e.g., Frissell et al. 1986, Kershner and Snider 1992). The effective conservation of intermittent rivers requires accurate characterization of the summer refugia, combining the pool features (physicalchemical, morphometrics) and biological data (assemblage composition and structure). Our hypothesis is that fish assemblages in each dry season pool are determined by local environmental conditions (morphometry and water quality) and regional drivers associated with their location on the river network (stream order, distance to source and to main river, stream width). In addition, we aimed to identify summer pool types in a southern Portuguese river network, based on the relationship between environmental conditions of the pools, their location on the river network, and fish assemblages. Finally, we discuss the implications for conservation and management.

\section{Methods}

\section{Study area}

The study was conducted in the Degebe River basin, located in the southern region of Portugal $\left(38^{\circ} 12^{\prime}-\right.$ $38^{\circ} 46^{\prime} \mathrm{N} ; 7^{\circ} 29^{\prime}-7^{\circ} 46^{\prime} \mathrm{W}$; Fig. 1). Sampling covered a large longitudinal gradient, from headwaters $(3 \mathrm{~km}$ from Degebe River source) to downstream reaches ( $4 \mathrm{~km}$ from the main river, Guadiana River). One of the main tributaries of the Guadiana River, Degebe River, is $79 \mathrm{~km}$ long and its drainage area is $1538 \mathrm{~km}^{2}$. The river basin is located in a lowland region with few low-altitude mountains; the mean annual temperature is $16^{\circ} \mathrm{C}$ and the mean annual precipitation is $550 \mathrm{~mm}$ (APA 2019). The climate is Mediterranean, with high intra- and interannual variability of precipitation and flow, unpredictable floods between autumn and spring (Oct-Mar), and summer droughts (Jun-Sep; Miranda et al. 2002). During the dry season period, lasting 4-5 months, the flow ceases and large sections of the streambed dry or shrink to isolated pools of variable size that remain as the only aquatic habitats until flow resumption. The degree of stream intermittency (i.e., the duration and intensity of the dry period) displays high interannual variation. The river hydrological regime depends largely on the precipitation regime, showing high interannual variability, and the mean (standard deviation [SD]) annual flow is $269.8(216.1) \mathrm{hm}^{3}$ on the Degebe River basin (APA 2019). Over the last 50 years of records, the duration of dry events was longer, resulting in extended drought periods (Matono et al. 2012, ARHA 2015). The studied year was hydrologically irregular, with high flow events in the winter and exceptionally low 

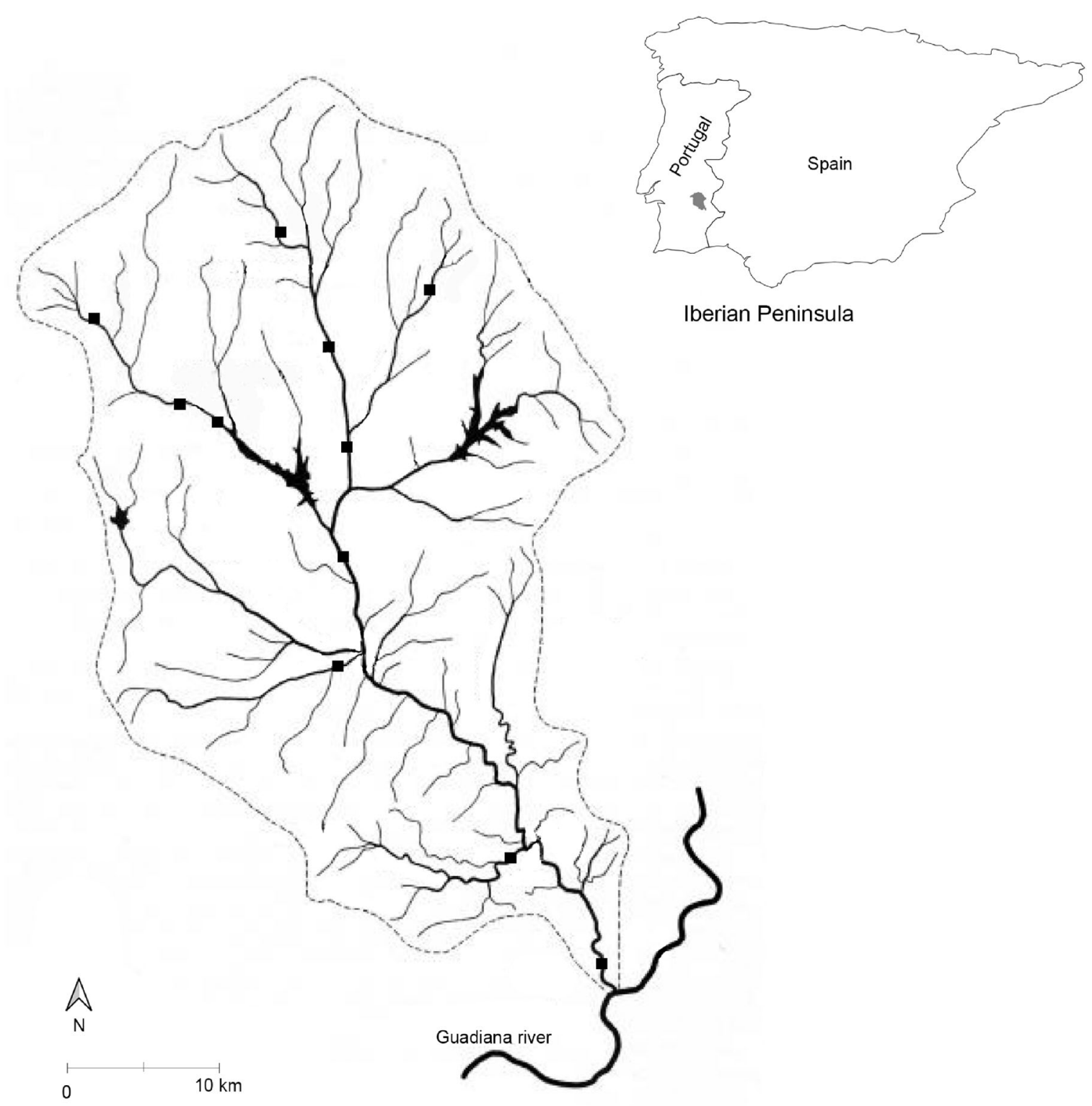

Iberian Peninsula

Figure 1. Location of the sampling sites in the Degebe River basin, southern Portugal.

discharge during the spring months (Bernardo et al. 2003).

Agroforestry (olive groves, vineyards, cereals, and cork oak) and livestock production (cattle, sheep, goats, and pigs) are the main land uses in the Degebe River basin and are responsible for the largest proportion of water demand $(>80 \%)$. The main anthropogenic pressures on these rivers are diffused agricultural pollution and organic loading, channelization, and water abstraction, which have led to significant water scarcity and quality problems as well as habitat degradation. Reduction of riparian vegetation by clear cutting or grazing is also a growing problem. The seasonality of flow regime, combined with high temperature and intense solar radiation in summer, enhances the vulnerability of the aquatic systems to anthropogenic pressures, leading to eutrophication and water quality degradation (Matono et al. 2013, 2019).

Southern Portuguese rivers have a large number of endemic fish species with high conservation status, although most fish assemblages present a relatively low species richness (Cabral et al. 2005). Native species are dominated by cyprinids, which are rapidly declining because of anthropogenic pressures (e.g., Matono et al. 2013, 2014). In the Degebe River basin, the most common and abundant fish species are Squalius alburnoides, Iberochondrostoma lemmingii, Luciobarbus microcephalus, L. steindachneri. Pseudochondrostoma willkommii and Luciobarbus comizo occur in much lower abundance, and non-native species are dominated mainly by Lepomis gibbosus (extremely abundant) Micropterus salmoides, and Australoheros facetum (Ilhéu 2004). 


\section{Environmental variables and fish sampling}

Sampling was conducted during the dry season, from 23 July to 7 September 1998, at 12 sites in the Degebe River basin (Fig. 1). At each site, a stream reach $500 \mathrm{~m}$ long was surveyed, including streambed width (mean stream wetted width, m), canopy (\% of stream area shaded by riparian vegetation), and dry riverbed (\% of dry riverbed area on each stream reach performed according to Ilhéu 2004). Stream order (Strahler 1952), distance to source $(\mathrm{km})$, and distance to the main river (the Guadiana River; $\mathrm{km}$ ) were obtained from digital cartography with free Internet access. In each stream reach, all existing pools were sampled once, totaling 128 units. A set of environmental variables describing the physical habitat and the water quality of each pool was measured: surface area $\left(\mathrm{m}^{2}\right)$, mean and maximum water depth $(\mathrm{cm})$, volume $\left(\mathrm{m}^{3}\right)$, percentage of aquatic vegetation cover (macrophytes and filamentous algae), and dominant substrate. The dominant substrate class was evaluated according to 6 classes adapted from the Wentworth scale (Giller and Malmqvist 1998): 1= fine sand and flat stone; $2=$ sand and gravel $(1-5 \mathrm{~mm}) ; 3=$ gravel and small pebbles $(5-50 \mathrm{~mm}) ; 4=$ cobbles $(50$ $-150 \mathrm{~mm}) ; 5=$ boulders $(150-500 \mathrm{~mm})$; and $6=$ large boulders $(>500 \mathrm{~mm})$. Water quality was based on physicochemical parameters measured in situ, including water temperature $\left({ }^{\circ} \mathrm{C}\right)$, dissolved oxygen $(\mathrm{DO}, \mathrm{mg} / \mathrm{L}), \mathrm{pH}$, conductivity $(\mu \mathrm{S} / \mathrm{cm})$. Temperature, $\mathrm{DO}$, and $\mathrm{pH}$ measurements were taken at 0700 $0730 \mathrm{~h}$, when the lowest values are observed, to allow a standardized comparison among pools. Additionally, water samples were collected at each pool before fish sampling to determine the concentration of nitrate- $\mathrm{N}\left(\mathrm{NO}_{3}^{-}, \mathrm{mg} / \mathrm{L}\right)$, phosphate- $\mathrm{P}\left(\mathrm{PO}_{4}^{3-}, \mathrm{mg} / \mathrm{L}\right)$, total dissolved phosphorus (TDP, $\mathrm{mg} / \mathrm{L}$ ), total suspended solids (TSS, mg/L), and water and periphytic chlorophyll $a$ (Chl- $a, \mu \mathrm{g} / \mathrm{L})$, following Clesceri et al. (1998).

Fish were collected using a backpack battery-powered electrofishing device (IG 200/2B, PDC Hans-Grassl $\mathrm{GmbH}$, Schönau am Königssee, Germany). To avoid escape response from fishes, operators stood still for 5-10 min before beginning electrofishing and, whenever possible, sampling was performed with the operators outside the water. Each pool was completely surveyed, covering the whole area. In deeper pools $(>120 \mathrm{~cm})$, fine-mesh nets (trammel nets) were used to isolate small sections prior to sampling to improve the capture efficiency. Fish were measured (total length, TL) and identified to species level, and native specimens were returned alive to the stream while non-natives were sacrificed. Small individuals $(<120 \mathrm{~mm}$ TL) of Luciobarbus spp. were grouped and named Luciobarbus spp. because of identification uncertainty.

\section{Data analysis}

Fish captures were quantified as catch per unit effort (CPUE) with $1 \mathrm{~min}$ as the unit effort. Fish assemblages were characterized considering both species composition and structure, for which several fish metrics were calculated in each stream pool: (1) species richness (S) and diversity ( $H$; Shannon and Weaver 1949); (2) community dominance (Dc, the sum of the relative frequencies of the 2 most abundant species); (3) abundance of small- to medium-sized native species ( $S$. alburnoides, S. pyrenaicus, I. lemmingii, Anaecypris hispanica, Cobitis paludica); (4) abundance of medium- to large-sized native species ( $P$. willkommii, L. microcephalus, L. steindachneri, and L. comizo); and (5) abundance of non-native species (Lepomis gibbosus, M. salmoides, A. facetum, Cyprinus carpio, and Carassius auratus). To account for the concentration effect, resulting in lower fishing efficiency in larger pools than in smaller pools, the relative abundance (proportion to total capture in each pool) of each species was calculated and used in statistical analyses. Species registering frequencies of occurrence $<5 \%$ were not considered.

A fundamental step in the definition of pool types based on fish fauna and environmental conditions requires the understanding of the relationship between these 2 components. In this sense, the relations between fish metrics (species richness and diversity) and environmental variables were evaluated using simple linear regressions (Sokal and Rohlf 1995), and canonical correspondence analysis (CCA) was used to relate fish assemblages (relative abundance of species) with environmental variables. A forward selection procedure ( $\alpha$ $<0.05)$ was used in the CCA to select environmental variables, and the statistical significance of the axes was determined with Monte Carlo permutation test with 999 permutations (Ter Braak and Smilauer 1998). The variation inflation factors of all selected variables did not exceed 20 to ensure the absence of multicollinearity issues (Ter Braak 1990).

To further untangle that relation and account for the possible interdependence between regional- (stream reach) and local- (pool) scale variables, the total variation in fish assemblages was partitioned into 4 independent components (Ter Braak 1990, Borcard et al. 1992, Rodriguez and Magnan 1995): (1) variation explained by stream reach variables; (2) variation explained by local variables; (3) "pure" variation explained by stream reach variables with no influence of local variables; and 
(4) "pure" variation explained by local variables with no influence of stream reach variables. The variation explained by each component was obtained through the quotient between the canonical values of each CCA and the total inertia. The pure variation of each group of variables was calculated through partial CCAs by removing the influence of the other groups of variables. The total explained variation resulted from the sum of components (1) and (4), or (2) and (3), while the shared variance for both groups of variables was calculated as the difference between components (3) and (1), or (2) and 4).

Pool types/groups were then defined by performing $K$-means, a nonhierarchical clustering classification method (Legendre 1999), on the ordination coordinates of pools obtained in the CCA. The Calinsky-Harabasz index (Legendre 1999) was used to validate the most adequate clustering number, and a one-way ANOVA table extracted from the $K$-means cluster analysis was used to evaluate the contribution of variables for differentiating pool types/groups. This approach was used to identify and aggregate similar pools.

The fidelity and specificity of fish species to pool types were evaluated through the INDVAL index (Dufrêne and Legendre 1997). This method allowed us to identify the indicator species of each pool type, combining the relative abundance of the species with their frequency of occurrence. The index reaches its maximum value $(100 \%)$ when a species is exclusively associated with one pool type and occurs in all the sampled pools of that type.

Significant differences in selected environmental variables between stream orders, reaches, and pool types were tested using Kruskal-Wallis and Mann-Whitney nonparametric tests. Statistical analyses were performed using the software CANOCO 4.0, IndVal 2.0, and SPSS 9.0. Prior to statistical analyses, fish metrics, species abundance, and environmental variables were either $\log _{10}(x+1)$ transformed or $\arcsin (\sqrt{ } x)$ transformed (percentages). The level of statistical significance was set at 0.05 .

\section{Results}

The stream reaches on the Degebe River network exhibited a high environmental heterogeneity (Table 1), but some differences among stream orders were observed. The percentage of dry riverbed was significantly higher $(P \leq 0.001)$ in headwater reaches (stream order 1$)$, all with values $>95 \%$, although all river sectors had reaches with $>90 \%$ of dry riverbed. Canopy was significantly higher $(P \leq 0.001)$ in first- and third-order reaches, although, in general, relatively low values were observed. The number of pools per stream reach was variable, ranging from 3 to 24 (mean $[\mathrm{SD}]=11$ [6.3]).

In general, pools showed high variability on environmental conditions within each stream order and no sharp differences among river sectors were found, excepting the morphometric variables. Pools located in first-order streams had significantly lower water volume and depth $(P \leq 0.001)$ as well as significantly finer dominant substrate $(P<0.001)$, whereas fourth-order stream pools were significantly larger $(P \leq 0.001)$ and tended to have deeper waters (up to $250 \mathrm{~cm}$ maximum water depth) and coarser substrate. No significant differences among stream orders were observed for most water quality variables, although pools in third and fourth orders tended to have lower conductivities and slightly higher $\mathrm{pH}$ and DO. Independent of stream order, most very small pools $\left(<1 \mathrm{~m}^{3}\right.$ and water depth $<20 \mathrm{~cm})$ showed very low DO $(<70 \%$ of saturation or $<3 \mathrm{mg} / \mathrm{L})$. Pools in the higher-order reaches had lower total phosphorus concentrations $(P \leq 0.001)$.

The primary productivity of pools was generally high, both in terms of phytoplankton and periphyton (Table 1), both expressed by Chl- $a$ concentration. In general, the aquatic vegetation cover was also abundant, although with high variability among pools, reaches, and stream orders. Dominant macrophytes were helophytes located in pool margins, namely Typha spp., Eleocharis spp., Juncus spp., and Paspalum paspalodes.

\section{Fish assemblages}

We captured 15 fish species in the sampled stream pools. S. alburnoides and L. gibbosus were the most abundant species and had the highest frequencies of occurrence ( $>50 \%$ of pools; Table 2$)$. Gambusia holbrooki was the most captured species, although with an extremely high standard deviation, evidencing the erratic character of this species. For that reason, this species was not considered for most of the analyses involving species proportional data.

CPUE values were notably high in most pools (mean $=539.0$ [738.1]). No fish were captured in 19 pools (14.8\% of all sampled pools), most with low volume $\left(<1 \mathrm{~m}^{3}\right)$ and located in first-order reaches; $47 \%$ of these pools dried out during the study period. Despite the variability in the number of species, pools with higher volumes tend to harbor more species and more diverse fish assemblages, and a significant regression between pools volume and species richness ( $S$ ) was observed $\left(r^{2}=0.69, P=0.001\right)$, as well as with species diversity (Shannon-Wiener index, $r^{2}=0.58, P=0.001$ ). 
Table 1. Environmental characterization of stream reaches and pools in the Degebe River network, using mean (SD) and range (minimum-maximum) for each stream order.

\begin{tabular}{|c|c|c|c|c|}
\hline \multirow[b]{2}{*}{ Environmental variables } & \multicolumn{4}{|c|}{ Stream order } \\
\hline & 1 st & 2nd & $3 \mathrm{rd}$ & 4th \\
\hline Reach $(n=12)$ & $(n=3)$ & $(n=3)$ & $(n=3)$ & $(n=3)$ \\
\hline \multirow{2}{*}{ Distance to source $(\mathrm{km})$} & $8.6(4.2)$ & $15.3(7.9)$ & $18.0(4.1)$ & $57.8(13.4)$ \\
\hline & $(3.0-12.0)$ & $(8.0-27.0)$ & $(14.0-22.0)$ & $(38.0-69.0)$ \\
\hline \multirow[t]{2}{*}{ Distance to main river: Guadiana $(\mathrm{km})$} & $60.0(7.7)$ & $47.8(13.5)$ & $46.0(4.1)$ & $15.2(13.4)$ \\
\hline & $(38.0-65.0)$ & $(18.0-56.0)$ & $(42.0-50.0)$ & $(4.0-35.0)$ \\
\hline \multirow[t]{2}{*}{ Streambed width (m) } & $10.2(2.2)$ & $8.3(2.6)$ & $13.5(1.5)$ & $25.5(6.3)$ \\
\hline & $(7.0-12.0)$ & $(3.0-10.0)$ & $(12.0-15.0)$ & $(15.0-30.0)$ \\
\hline \multirow[t]{2}{*}{ Canopy $(\%)^{* *}$} & $27.0(31.5)$ & $13.3(2.6)$ & $30.5(10.3)$ & 9.1 (19.6) \\
\hline & $(0.0-70.0)$ & $(0.0-40.0)$ & $(20.0-40.0)$ & $(0.0-50.0)$ \\
\hline \multirow[t]{2}{*}{ Dry riverbed $(\%)^{* *}$} & $97.7(1.4)$ & $89.3(7.1)$ & $81.7(19.8)$ & $73.2(18.2)$ \\
\hline & $(96.0-99.4)$ & $(79.0-94.0)$ & $(59.0-91.0)$ & $(57.0-91.0)$ \\
\hline \multirow{3}{*}{$\begin{array}{l}\text { Pool }(n=128) \\
\text { Volume }\left(m^{3}\right)^{* *}\end{array}$} & $(n=40)$ & $(n=27)$ & $(n=24)$ & $(n=37)$ \\
\hline & $33.1(49.3)$ & $56.3(79.9)$ & $78.2(121.6)$ & $104.7(219.8)$ \\
\hline & $(0.05-175.0)$ & $(1.8-300.0)$ & $(0.7-420.0)$ & $(0.03-937.5)$ \\
\hline \multirow[t]{2}{*}{ Maximum depth $(\mathrm{cm})^{* *}$} & $48.0(28.4)$ & $63.9(36.2)$ & $60.8(39.6)$ & $64.1(62.2)$ \\
\hline & $(4.0-120.0)$ & $(15.5-170.0)$ & $(15.0-170.0)$ & $(6.0-250.0)$ \\
\hline \multirow[t]{2}{*}{ Dominant substrate class $(1-6)^{* *}$} & $1.9(0.3)$ & $2.1(0.6)$ & $2.7(1.3)$ & $2.7(1.1)$ \\
\hline & $(1.0-2.4)$ & $(1.2-3.3)$ & $(1.5-6.0)$ & $(1.5-6.0)$ \\
\hline \multirow[t]{2}{*}{ Boulders/refuge (\%) } & $13.2(20.9)$ & $6.1(8.9)$ & $29.4(34.7)$ & $17.0(25.3)$ \\
\hline & $(0.0-80.0)$ & $(0.0-30.0)$ & $(0.0-100.0)$ & $(0.0-100.0)$ \\
\hline \multirow[t]{2}{*}{ Aquatic vegetation cover (\%) } & $30.6(28.0)$ & $19.2(24.5)$ & $26.0(22.2)$ & $28.6(32.2)$ \\
\hline & $(0.0-100.0)$ & $(0.0-100.0)$ & $(0.0-80.0)$ & $(0.0-100.0)$ \\
\hline \multirow[t]{2}{*}{ Water temperature $(0700 \mathrm{~h})\left({ }^{\circ} \mathrm{C}\right)$} & $20.5(1.7)$ & $20.9(2.1)$ & $20.8(1.5)$ & $20.6(1.6)$ \\
\hline & $(17.0-23.6)$ & $(16.0-26.2)$ & $(18.0-24.0)$ & $(17.0-25.0)$ \\
\hline \multirow[t]{2}{*}{ Dissolved oxygen $(0700 \mathrm{~h})(\mathrm{mg} / \mathrm{L})$} & $3.5(0.8)$ & $3.7(1.7)$ & $3.3(1.2)$ & $3.9(1.7)$ \\
\hline & $(2.0-6.0)$ & $(0.5-7.6)$ & $(1.0-5.3)$ & $(0.8-6.2)$ \\
\hline \multirow[t]{2}{*}{ pH $(0700$ h) } & $7.2(0.6)$ & $7.3(0.6)$ & $7.5(0.6)$ & $7.7(0.8)$ \\
\hline & $(6.0-8.3)$ & $(5.7-8.9)$ & $(6.0-9.2)$ & $(6.7-9.9)$ \\
\hline \multirow[t]{2}{*}{ Conductivity $(\mu \mathrm{S} / \mathrm{cm})$} & $826(567)$ & $840(480)$ & $692(236)$ & $771(310)$ \\
\hline & $(240-2650)$ & $(143-2000)$ & $(142-1120)$ & (141-1700) \\
\hline \multirow{2}{*}{ Phosphate (mg/L) } & $0.1(0.1)$ & $0.04(0.03)$ & $0.1(0.03)$ & $0.04(0.1)$ \\
\hline & $(0.0-0.5)$ & $(0.0-0.1)$ & $(0.0-0.1)$ & $(0.0-0.4)$ \\
\hline \multirow[t]{2}{*}{ Total phosphorus $(\mathrm{mg} / \mathrm{L})^{* *}$} & $0.4(0.3)$ & $0.4(0.2)$ & $0.3(0.2)$ & $0.2(0.2)$ \\
\hline & $(0.0-0.8)$ & $(0.0-0.8)$ & $(0.1-0.7)$ & $(0.0-0.8)$ \\
\hline \multirow[t]{2}{*}{ Nitrate (mg/L) } & $0.3(0.4)$ & $0.2(0.2)$ & $0.3(0.4)$ & $0.5(0.8)$ \\
\hline & $(0.0-1.6)$ & $(0.0-0.8)$ & $(0.0-2.0)$ & $(0.0-4.3)$ \\
\hline \multirow[t]{2}{*}{ Total suspended solids $(\mathrm{mg} / \mathrm{L})^{* *}$} & $29.2(19.2)$ & $78.6(102.7)$ & $32.9(17.1)$ & 19.4 (14.6) \\
\hline & $(5.9-74.7)$ & $(4.8-484.0)$ & $(13.4-75.2)$ & $(5.8-70.9)$ \\
\hline \multirow[t]{2}{*}{ Water chlorophyll $a(\mu \mathrm{g} / \mathrm{L})$} & $26.0(34.9)$ & $16.9(19.2)$ & $17.2(24.8)$ & $21.3(16.7)$ \\
\hline & $(0.9-163.1)$ & $(0.0-85.3)$ & $(0.0-97.4)$ & $(0.3-67.8)$ \\
\hline \multirow{2}{*}{ Periphytic chlorophyll $a(\mu \mathrm{g} / \mathrm{L})^{* *}$} & $101.9(56.2)$ & $54.0(34.8)$ & $81.7(36.1)$ & $86.4(52.4)$ \\
\hline & $(19.4-252.2)$ & (11.3-129.2) & $(1.1-143.3)$ & $(17.7-294.4)$ \\
\hline
\end{tabular}

$P$-levels are for significant difference between stream orders $\left({ }^{*} P \leq 0.05,{ }^{* *} P \leq 0.001\right.$ Kruskal-Wallis and Mann-Whitney), in bold.

Table 2. Fish species in the pools of Degebe River network: occurrence (\% Occ), CPUE (captures per minute).

\begin{tabular}{lcc}
\hline Species & \% Occ & CPUE mean (SD) \\
\hline Natives & & \\
Squalius alburnoides & 89.3 & $192.9(252.5)$ \\
lberochondrostoma lemmingii & 50.5 & $56.5(119.2)$ \\
Squalius pyrenaicus & 45.6 & $20.1(67.5)$ \\
Cobitis paludica & 36.9 & $16.8(95.0)$ \\
Pseudochondrostoma willkommii & 17.5 & $1.9(6.5)$ \\
Luciobarbarbus spp. (juveniles TL<120 mm) & 29.7 & $29.6(113.1)$ \\
Luciobarbus microcephalus & 17.5 & $6.9(47.7)$ \\
Luciobarbus steindachneri & 15.5 & $3.3(16.9)$ \\
Luciobarbus comizo & 8.7 & $0.2(1.0)$ \\
Anaecypris hispanica & 2.9 & $0.01(0.1)$ \\
Non-natives & & \\
Lepomis gibbosus & 71.8 & $70.0(141.2)$ \\
Australoheros facetum & 18.4 & $13.4(55.8)$ \\
Cyprinus carpio & 17.5 & $0.8(2.7)$ \\
Micropterus salmoides & 11.7 & $1.2(5.5)$ \\
Carassius auratus & 3.9 & $0.2(1.4)$ \\
Gambusia holbrooki & 30.9 & $456.9(1072.8)$ \\
\hline
\end{tabular}

Native species were dominant in most of the pools and were absent from only 6 pools, exclusively occupied by $L$. gibbosus. Medium- to large-sized native species represented a small fraction of the total fish captures. Non-native species, dominated by $L$. gibbosus and A. facetum, occurred in $>50 \%$ of the sampled pools, representing on average $\sim 30 \%$ of fish assemblages.

\section{Fish-environmental relationship and pool types}

All stream reach variables were retained by the CCA, explaining about $24 \%$ of the total variation of fish assemblages $(P=0.01$; Table 3 , Fig. 2). The variation explained by these variables was $16.0 \%$. The first axis (48.1\% of variation explained) was negatively correlated with the distance to the Guadiana River and positively 
Table 3. Canonical correspondence analysis (CCA) partial model synthesis between fish assemblages and regional variables (proper values: 1 st axis $=0.45,2$ nd axis $=0.30$ ) and local abiotic variables (proper values: 1 st axis $=0.22,2$ nd axis $=0.17$ ) included by forward selection.

\begin{tabular}{|c|c|c|c|c|c|c|c|}
\hline \multirow[b]{2}{*}{ Environmental Variables } & \multicolumn{3}{|c|}{ Variables ("Forward selection") } & \multicolumn{2}{|c|}{ Canonical coefficients } & \multicolumn{2}{|c|}{$\begin{array}{c}\text { Correlation with } \\
\text { canonical axis }\end{array}$} \\
\hline & Extra-fit & $F$-value & $p$-value & Axis 1 & Axis 2 & Axis 1 & Axis 2 \\
\hline Stream order & 0.35 & 11.18 & 0.005 & $0.26^{*}$ & $-1.05^{* *}$ & $0.64^{* *}$ & $-0.34^{* *}$ \\
\hline Distance to source $(\mathrm{km})$ & 0.31 & 9.73 & 0.005 & $-0.22^{*}$ & -0.18 & $0.66^{* *}$ & -0.06 \\
\hline Distance to the main river $(\mathrm{km})$ & 0.43 & 14.09 & 0.005 & $-0.74^{* *}$ & $-0.30^{*}$ & $-0.80^{* *}$ & -0.11 \\
\hline Streambed width (m) & 0.27 & 8.48 & 0.005 & 0.10 & $0.74^{* *}$ & $0.60^{* *}$ & 0.10 \\
\hline Canopy (\%) & 0.10 & 2.98 & 0.005 & 0.02 & $-0.35^{* *}$ & $-0.22^{*}$ & $-0.27^{*}$ \\
\hline \multicolumn{8}{|l|}{ Local/pool } \\
\hline Volume $\left(\mathrm{m}^{3}\right)$ & 0.14 & 4.32 & 0.005 & -0.12 & $-0.54^{* *}$ & 0.16 & $-0.37^{* *}$ \\
\hline Maximum depth $(\mathrm{cm})$ & 0.09 & 2.78 & 0.02 & 0.08 & 0.08 & 0.13 & $-0.29 * *$ \\
\hline Dominant substrate class (1-6) & 0.09 & 2.74 & 0.02 & $0.26^{*}$ & 0.01 & $0.36^{* *}$ & 0.06 \\
\hline Aquatic vegetation cover (\%) & 0.07 & 2.12 & 0.06 & -0.12 & $0.20^{*}$ & -0.09 & $0.24^{*}$ \\
\hline Dissolved oxygen (mg/L) & 0.13 & 3.87 & 0.005 & 0.15 & $0.45^{* *}$ & $0.23^{*}$ & $0.21^{*}$ \\
\hline Water temperature $\left({ }^{\circ} \mathrm{C}\right)$ & 0.07 & 1.96 & 0.005 & $0.17^{*}$ & -0.04 & $0.22^{*}$ & -0.18 \\
\hline $\mathrm{pH}$ & 0.11 & 3.41 & 0.005 & 0.18 & -0.12 & $0.33^{* *}$ & -0.05 \\
\hline Nitrate-N (mg/L) & 0.07 & 2.09 & 0.09 & $0.29 * *$ & 0.12 & $0.22^{*}$ & 0.04 \\
\hline Phosphate $(\mathrm{mg} / \mathrm{L})$ & 0.06 & 1.85 & 0.08 & $-0.43^{* *}$ & -0.03 & $-0.28^{* *}$ & 0.02 \\
\hline
\end{tabular}

$P$-levels are given for variables significantly related to the axis $\left({ }^{*} P \leq 0.05,{ }^{*} P \leq 0.001\right)$.

correlated with distance to source, stream order, and streambed width. This axis discriminated fish assemblages of headwaters (small- to medium-sized native species such as I. lemmingii, S. alburnoides, and Squalius pyrenaicus) from larger-sized species typical of downstream sectors, both native (Luciobarbus spp. and $P$. willkommii) and non-native ( $M$. salmoides and A. facetum). The second axis $(31.7 \%$ of variation explained) was mainly defined by stream order and canopy cover. Pools located in upstream sections with high cover values provided by riparian vegetation were associated with L. gibbosus and Cyprinus carpio while those with low cover values were associated with C. paludica.

Regarding pool environmental variables, only 9 were retained in the CCA (Table 3), accounting for $18.4 \%$ of (a)

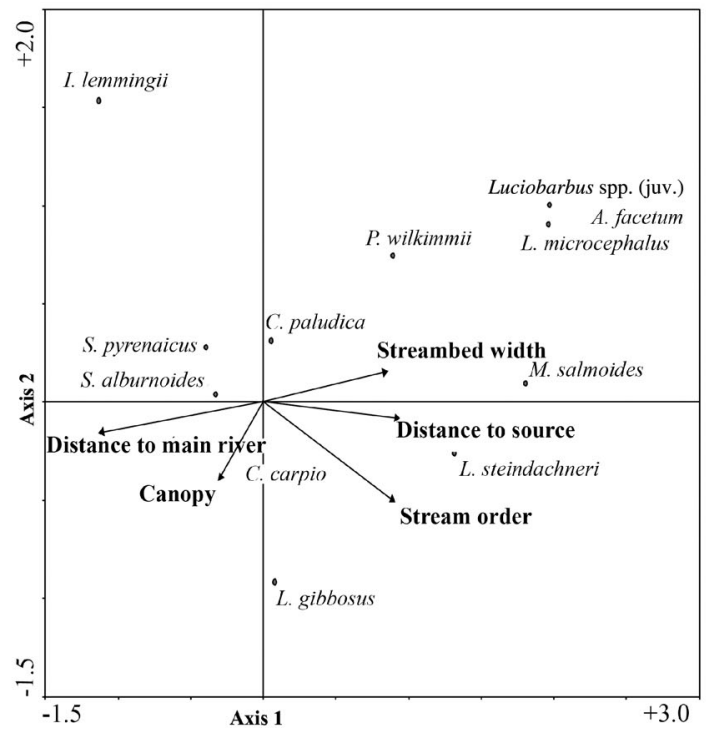

(b)

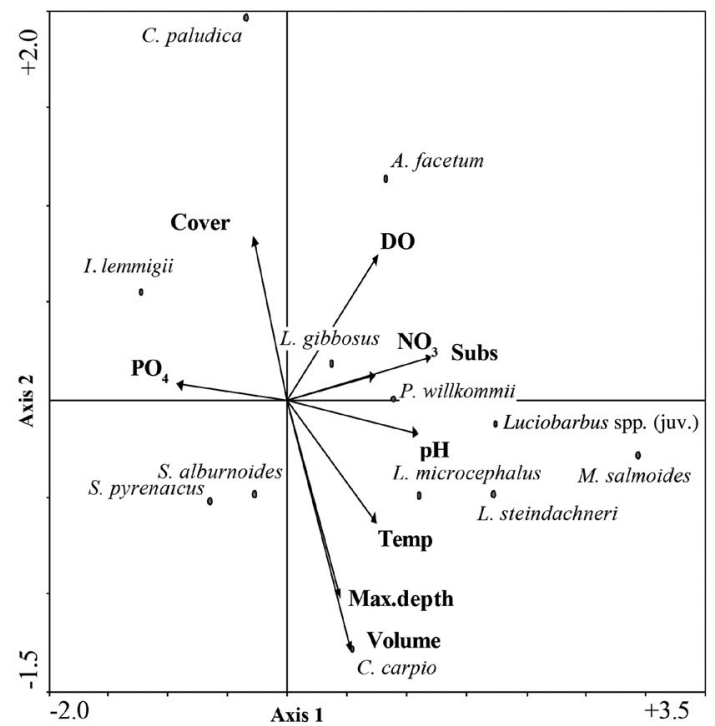

Figure 2. (a) Fish species ordination from a canonical correspondence analysis (CCA) based on reach variables: Canopy (\% of riparian vegetation shadowing), Distance to main river (distance to the Guadiana River, km), Distance to source (km), Streambed width (m), and Stream order (Strahler classification). Points and arrows represent species and environmental variables by pool, respectively. (b) Fish species ordination from a CCA based on abiotic local/pool variables. Points and arrows represent species and environmental variables by pool, respectively. Volume $\left(\mathrm{m}^{3}\right)$, Max.depth (maximum depth, $\mathrm{cm}$ ), Subs (dominate substrate class, 1-6), Cover (\% of aquatic vegetation cover), DO (dissolved oxygen concentration at $0700 \mathrm{~h}, \mathrm{mg} / \mathrm{L}$ ), Temp (water temperature at $\left.0700 \mathrm{~h},{ }^{\circ} \mathrm{C}\right), \mathrm{pH}\left(\right.$ at $0700 \mathrm{~h}$ ), $\mathrm{PO}{ }_{4}$ (phosphate concentration, $\mathrm{mg} / \mathrm{L}$ ), and $\mathrm{NO}_{3}$ (nitrate- $\mathrm{N}$ concentration, $\mathrm{mg} / \mathrm{L}$ ). 
the total variation of fish assemblages $(P=0.01)$. The pure variation explained by local variables was $10.7 \%$. The first axis (32.5\% of variation) reflected mainly habitat attributes, both physical and chemical, discriminating small- to medium-sized species from larger ones. The second axis $(24.2 \%$ of variation) was mostly defined by water volume and maximum depth, DO, and percentage of aquatic cover.

The $K$-means classification, based on pool coordinates in the CCA axis, defined 4 pool types resulting from the best solution and the highest value of Calinski-Harabasz pseudo $F$ statistic $=269.2 \quad(\mathrm{SSE}=26.18$; Fig. 3). An additional type was defined (Type 0) corresponding to the group of pools without fish captures, which was not projected in the CCA ordination (absent data). This pool type is important to fully understand life history strategies of fish species and the factors underpinning assemblages structuring.

Pool types reflect 2 main environmental gradients (Fig. 4), one related to location (stream order, distance to the main river) and the other to pool size, both determining fish assemblages composition and structure (Table 4).

Type 0 is significantly different from all the others $(P \leq 0.001)$, including very small and shallow pools (many $<20 \mathrm{~cm}$ depth), mainly from upstream reaches with high vegetation cover and low DO concentration (Table 4). Type 1 is constituted by small pools with low water volume and depth (most $<40 \mathrm{~m}^{3}$ and with maximum depths $<30 \mathrm{~cm}$ ) and high vegetation cover, located

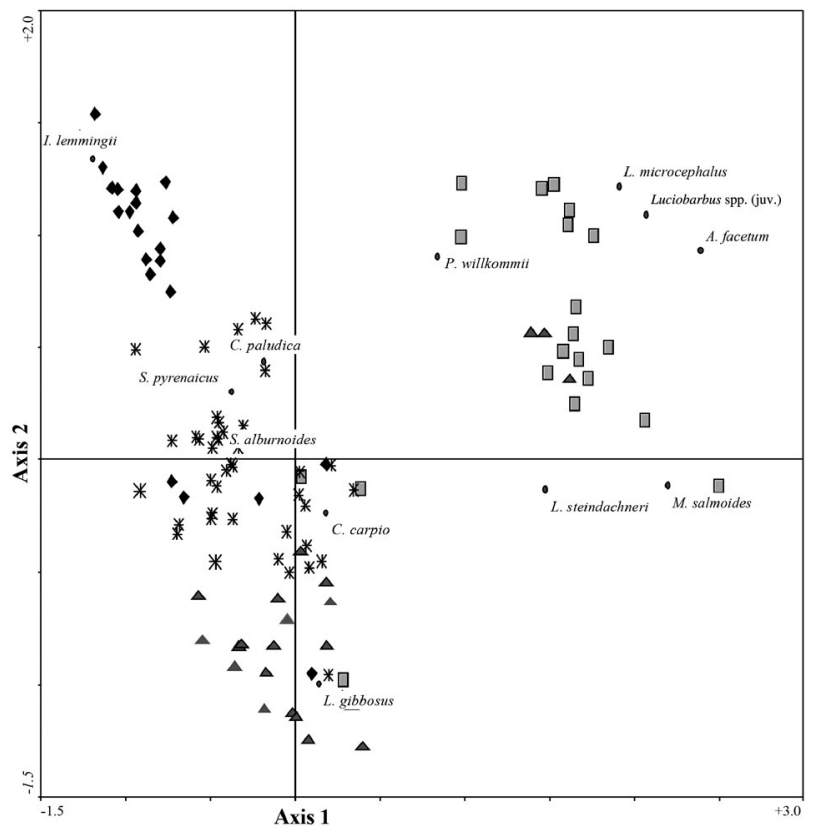

Figure 3. K-means classification projection indicating the 4 fishbased pool types.

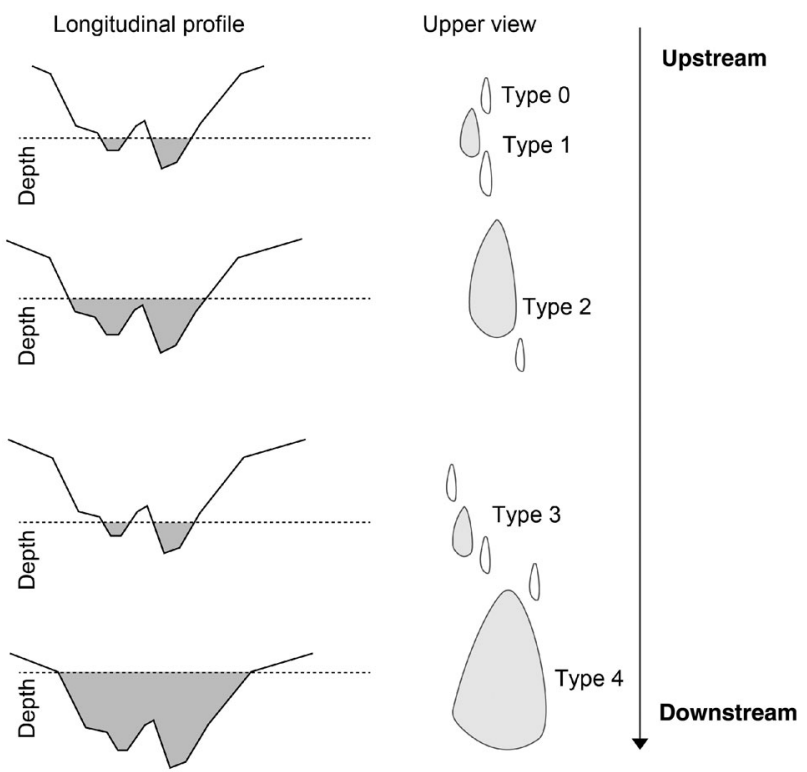

Figure 4. Scheme of pools types along the river longitudinal gradient from upstream to downstream sectors. Small pools with no fish (Type 0) are represented in white. The remain types are represented with gray color, according to pool size.

in upstream reaches (first and second stream orders). Periphytic productivity was significantly higher $(P \leq$ 0.001 ) in this pool type, where fish assemblages were mainly composed of small- to medium-sized native generalists, including I. lemmingii and C. paludica, the indicator species. Pool Types 0 and 1 exhibited high nutrient concentration, particularly phosphate. Type 2 , the most numerous type, groups larger pools, many with maximum water depth $>70 \mathrm{~cm}$, in upstream reaches dominated by small- to medium-sized native species, with S. alburnoides as the indicator species. Type 3 includes small pools, similar to Type 1, but located in downstream sectors, with fish assemblages dominated by L. gibbosus. Type 4 is formed by high-volume pools, located mostly in downstream sections (fourth stream order), with significantly $(P \leq 0.001)$ higher DO values as well as lower concentrations of phosphorus and TSS (both $P \leq 0.001$ ). Type 4 showed high diversity and species richness with fish assemblages defined by Luciobarbus species and A. facetum, and a significant proportion of native medium-to-large species. Larger individuals (TL $>$ $250 \mathrm{~mm}$ ) occurred exclusively in Types 4 and 2 (i.e., in the deeper pools).

\section{Discussion}

The results from the present study confirm the hypothesis that pool types and their fish assemblages are determined by regional drivers (location on the river network) and by local environmental features (pool 
Table 4. Environmental variables (mean [SD]) and fish metrics for each pool type in the Degebe River network.

\begin{tabular}{|c|c|c|c|c|c|}
\hline \multirow[b]{2}{*}{ Environmental Variables } & \multicolumn{5}{|c|}{ Pool Types } \\
\hline & $0(n=19)$ & $1(n=23)$ & $2(n=46)$ & $3(n=20)$ & $4(n=20)$ \\
\hline Stream order** & $2.1(1.3)$ & $1.3(0.8)$ & $2.2(0.9)$ & $3.4(0.7)$ & $3.8(0.6)$ \\
\hline Distance to source $(\mathrm{km})^{* *}$ & 18.48 (17.2) & $12.7(7.0)$ & $15.4(11.3)$ & $35.1(20.3)$ & $61.2(15.6)$ \\
\hline Distance to main river $(\mathrm{km})^{* *}$ & $51.0(16.0)$ & $57.7(11.0)$ & $49.5(11.2)$ & 34.8 (17.3) & $8.4(7.6)$ \\
\hline Volume $\left(\mathrm{m}^{3}\right)^{*}$ & $0.61(1.1)$ & $15.5(25.8)$ & $71.9(98.2)$ & $14.9(22.2)$ & $175(265.1)$ \\
\hline Max. water depth $(\mathrm{cm})^{*}$ & $15.6(14.3)$ & $44.3(30.2)$ & $63.3(36.5)$ & $49.1(33.1)$ & $78.2(72.2)$ \\
\hline Substrate class $(1-6)$ & $1.7(0.5)$ & $1.9(0.5)$ & $2.2(0.5)$ & $2.6(2.2)$ & $3.0(1.2)$ \\
\hline Boulders/refuge (\%) & 0.0 & $10.8(18.7)$ & $10.4(16.5)$ & $23.3(35.7)$ & $25.5(28.4)$ \\
\hline Aquatic vegetation cover (\%) & $30.4(37.0)$ & $38.4(33.2)$ & $22.0(21.0)$ & $24.0(29.0)$ & $25.3(30.7)$ \\
\hline Water temperature $\left({ }^{\circ} \mathrm{C}, 0700 \mathrm{~h}\right)$ & $19.8(1.9)$ & $20.0(1.6)$ & $20.9(1.8)$ & $20.8(1.3)$ & $20.8(2.0)$ \\
\hline Dissolved oxygen $(\mathrm{mg} / \mathrm{L}, 0700 \mathrm{~h})^{*}$ & $2.2(1.4)$ & $3.6(1.0)$ & $2.8(1.4)$ & $3.0(1.2)$ & $4.8(1.2)$ \\
\hline pH (0700 h) & $6.9(0.5)$ & $7.2(0.6)$ & $7.3(0.6)$ & $7.3(0.4)$ & $8.0(0.9)$ \\
\hline Conductivity $(\mu \mathrm{S} / \mathrm{cm})$ & $812.6(378)$ & $635.5(221)$ & $766.0(342)$ & 853.7 (376) & $812.1(627)$ \\
\hline Total suspended solids $(\mathrm{mg} / \mathrm{L})^{* *}$ & $37.5(29.7)$ & $24.6(14.2)$ & $45.7(46.2)$ & $60.4(104.4)$ & $16.3(15.0)$ \\
\hline Phosphate $(\mathrm{mg} / \mathrm{L})^{*}$ & $0.16(0.24)$ & $0.16(0.16)$ & $0.05(0.04)$ & $0.05(0.08)$ & $0.04(0.04)$ \\
\hline Total phosphorus $(\mathrm{mg} / \mathrm{L})^{* *}$ & $0.37(0.32)$ & $0.39(0.27)$ & $0.32(0.22)$ & $0.32(0.25)$ & $0.12(0.12)$ \\
\hline Nitrate-N (mg/L) & $0.66(1.1)$ & $0.37(0.45)$ & $0.23(0.32)$ & $0.30(0.35)$ & $0.52(0.94)$ \\
\hline Water chlorophyll $a(\mu \mathrm{g} / \mathrm{L})$ & $21.8(23.2)$ & $22.8(25.9)$ & $19.8(28.7)$ & $23.1(23.7)$ & $18.3(13.9)$ \\
\hline \multicolumn{6}{|l|}{ Fish assemblages } \\
\hline Species richness $(S)^{* *}$ & 0 & $3.9(1.3)$ & $4.9(1.9)$ & $2.7(1.2)$ & $6.2(2.7)$ \\
\hline Species diversity $(H)^{* *}$ & 0 & $0.8(0.3)$ & $0.8(0.4)$ & $0.4(0.3)$ & $1.2(0.5)$ \\
\hline Community dominance (Dc \%)* & 0 & $0.9(0.1)$ & $0.9(0.1)$ & $1.0(0.04)$ & $0.7(0.1)$ \\
\hline Native small-medium size species (\%)** & 0 & $99.3(1.0)$ & $78.0(17.0)$ & $14.1(15.0)$ & $49.3(30.0)$ \\
\hline Native medium-large size species $(\%)^{* *}$ & 0 & $0.03(0.2)$ & $1.0(2.1)$ & $0.1(0.1)$ & $16.0(20.0)$ \\
\hline Non-native species $(\%)^{* *}$ & 0 & $1.0(1.0)$ & $20.0(17.0)$ & $81.0(24.0)$ & $34.0(30.0)$ \\
\hline \multirow[t]{2}{*}{ Indicator species* (IndVal) } & - & I. lemmingii & S. alburnoides & L. gibbosus & A. facetum \\
\hline & & $\begin{array}{l}\text { C. paludica } \\
(51.3 \%)\end{array}$ & & & $\begin{array}{l}\text { Luciobarbus spp. } \\
(73.4 \%)\end{array}$ \\
\hline
\end{tabular}

$P$-levels are for significantly different pool types $\left({ }^{*} P \leq 0.05,{ }^{* *} P \leq 0.001\right.$ Kruskal-Wallis and Mann-Whitney), in bold.

morphometry and water quality) and emphasize the importance of pool dimensions on environmental quality and fish assemblage characteristics. The 4 pool types differ in location and size and have distinct fish assemblages.

Pool features and conditions presented a high environmental variability in general and also within each stream order. No sharp differences on pool characteristics were observed among stream orders, but we observed an upstream-downstream gradient of water volume and depth, both increasing with stream order. Regarding water characteristics, pools located in higher orders tended to have lower conductivity, slightly higher oxygen concentration and $\mathrm{pH}$, and more stable environmental conditions (smaller daily variation of water temperature and oxygen; MI and JMB, unpubl. data). Those pools were in general larger, deeper, and more persistent. The groundwater input, particularly relevant in deep larger pools, may favor these habitats by reducing the thermal extremes, which could cause hyperthermia in fish (Labbe and Fausch 2000). In addition to the thermal refugia, the larger downstream pools (Type 4) may provide also higher refuge value for fish related to the coarser substrate, which tended to be well represented in this type of pool. Accordingly, these pools represent safer environments for the aquatic biota. Conversely, pools without fish (Type 0) had markedly low depth and absence of refuge elements, high eutrophication, and markedly low DO at dawn. During summer, shallow pools shrink markedly, and higher concentrations of suspended solids and dissolved nutrients, namely phosphorus, create a harsh environment for fish.

Regional scale variables, in particular stream order and distance to the main river, play a relevant role in the fish species distribution and assemblage structure (e.g., Leftwich et al. 1997, Torgersen et al. 1999, Labbe and Fausch 2000) also in dry season stream pools. The location of pools within the river system and the proximity to larger and more persistent waterbodies acting as potential propagule sources are relevant factors of species diversity, as observed in other studies (Ricklefts and Schluter 1993), and determine the pattern and distribution of fish species. Species richness increased with stream order, mostly because of the presence in the downstream reaches of large, more persistent, and benign pools.

Pool types of the Degebe River were defined by crossing large- and small-scale factors. The pool patterns along the river network seem to be primarily controlled by large-scale factors determining the pool morphometries in each sector as well as the fish assemblages structure (e.g., species richness and diversity, size class); within each river sector, local variables, mainly related to pool dimensions, determine the environmental conditions, namely water quality, and the fish composition. Both types of variables are addressed by the Theory of 
Island Biogeography (TIB; MacArthur and Wilson 1967), a major contribution to the diversity theory that is also relevant to the interpretation of pool assemblages. Summer pools are isolated environmental units, or "islands" in the context of TIB. The number of species on any island reflects a balance between the rate at which new species colonize it and the rate at which populations of established species become extinct. Nearer sources of dispersion promote a more effective colonization than distant sources. Every summer, part of the streambed dries up, and in years of dry spring and hot summer, streams and rivers such as Degebe dry almost completely. During the following wet period, reaches located near the Guadiana River (the main river of this network) receive new colonizing species at a higher rate than the distant headwater reaches. Species diversity is also the result of local extinctions caused by availability of resources and biotic interactions, which are related to the island area. Larger pools present higher heterogeneity and availability of resources, lowering extinction rates, and therefore the number of species over time is higher than in smaller pools. The observed relationship between pool volumes and number of fish species is consistent with TIB, in accordance with previous studies attesting that the number of species and diversity increase with depth, volume, and pool persistence (e.g., Schlosser 1982, 1987, Taylor 1997, Dekar and Magoulick 2007).

Fish behavior related to risk perception (Schlosser 1988, Capra et al. 2017) is also relevant to understanding the pool assemblages. Predation risk potentially affects the distribution of fishes; in shallow habitats, large fish face the highest risk from wading, non-gape-limited predators (mammals, birds), whereas in deep habitats small fish face the highest risk from swimming, gape-limited predators (fishes; e.g., Power 1987, Schlosser 1988). This behavior was evident in the summer pools, where a strong relationship between pool depth and fish size was observed. In the extreme case of very shallow pools (Type 0), fish were absent for several possible reasons: (1) avoidance of those habitats before they become isolated, (2) all the confined fishes were depredated by mammals and birds, or (3) fish died from extreme environmental conditions. Small pools had only smallersized fish species, mainly in headwater streams (Type 1) but in higher orders as well (Type 3), whereas largersized species mainly occurred in deep pools, mostly located in higher-order streams (Type 4). This "bigger fish-deeper habitat" pattern (Harvey and Stewart 1991) was also reported in other studies (e.g., Power 1984, Schlosser 1988, Harvey and White 2017).

Patterns of life history with distinct strategies are also important to understand fish species distribution in summer pools. The native generalist species of smallto medium-sized with $r$ selection (Pianka 1970) and opportunistic strategy (small adult size, short-lived, early maturation; Winemiller and Rose 1992), such as S. alburnoides, were markedly abundant in the small upstream pools of Type 1 . These waterbodies tend to be less persistent and frequently have critical conditions (high temperatures, hypoxia). Larger-sized fish species, such as Luciobarbus spp. or P. willkommii, present a periodic strategy (large body size, long lifespan, long generation time, high batch fecundity; Winemiller and Rose 1992) adapted to lower risk reaches (higherorder streams) and more stable environments (large persistent pools: Type 4). The small- to medium-sized native species seem to respond to environmental pressures and higher mortality risk with physiological and reproductive strategies responsible for a high resilience, whereas medium- to large-sized native species respond through strategies of habitat selection involving movements within the river network (Ilhéu 2004, Datry et al. 2014, Pires et al. 2014), choosing deep reaches during the dry season to avoid more risky environments.

The large proportion of non-native individuals in downstream reaches may result from the higher availability of lentic conditions during the wet season (Ilhéu et al. 2014, Matono et al. 2018). These characteristics are advantageous for non-native limnophilic species such as centrarchids because of their preference for standing waters, whereas in headwater reaches they face a higher risk of entrainment (e.g., Meffe 1984, Castelberry and Cech 1986, Matthews 1986, Bernardo et al. 2003). An upstream-downstream gradient, changing from native to non-native species dominance, was also described by Cid et al. (2017). The dominance of L. gibbosus, particularly small individuals, was also observed in small pools located in higher orders (Type 3), which may result from their choice for marginal areas with low-to-medium depth (Ilhéu 2004). During summer, as water depth decreases, smaller pools may form from the fragmentation of larger pools, and L. gibbosus individuals may remain confined in these pools. This species is adapted to high temperatures and low dissolved oxygen (Matthews 1998), which may explain its persistence in harsh environmental conditions (Minckley 1973, 1983, Arthington 1991) such as small marginal pools.

\section{Implications for conservation and management}

In intermittent rivers, summer pools represent simultaneously the only refuge for the aquatic biota during the dry season, which lasts for 5 or more months, and the propagule sources for the recolonization of the rivers network. The pool types resulting from this study allowed us to discriminate fish assemblages and local environmental conditions, particularly habitat size and 
water quality, according to pool location on the river network. The spatial heterogeneity of the pool environments seems to play a determinant role on species sorting, providing adequate conditions for a diverse array of species with different habitat requirements. From a conservation point of view, it is therefore essential to maintain or improve the availability, quality, and heterogeneity of pools along the river network.

The conservation and effective management of intermittent rivers and their biota is prompting researchers to develop methods to assess the river status also during the summer, particularly because natural and humaninduced disturbance tend to act synergistically (Matono et al. 2012, 2014). The European Water Framework (Directive 2000/60/EC 2000) requires an assessment of the ecological status of waterbodies and the achievement of "good ecological status" or better for all surface waterbodies. To assure the maintenance or improvement of the ecological quality in intermittent rivers, in addition to the current challenges regarding their status assessment (e.g., Stubbington et al. 2018), specific monitoring programs should be designed for the dry period, in which pool reference conditions are essential. The identification of pool types relevant to support the aquatic biodiversity or particular threatened species is a first step, allowing us to set monitoring programs and assess cumulative impacts of human activities on rivers and their biota.

Many intermittent rivers and stream in southern Europe are intercepted by dams, which change the physical and chemical characteristics of downstream sectors and therefore the environmental conditions of summer pools. The particular constraints of these ecosystems require the development of environmental flow methods that take into account the allocation of a flow regime compatible with the persistence of summer pools with good status (Bernardo and Alves 1999), ensuring the most favorable conditions for the distinct fish assemblages or for particular target species.

Intermittent rivers are expected to become more widespread and are facing increasing pressures in many regions as a result of human activities and climate change. In this context, the knowledge, maintenance, and improvement of the most valuable pool types for conservation and management are extremely important and urgent tasks.

\section{Acknowledgements}

We thank the former Instituto da Água, now Agência Portuguesa do Ambiente, and Fundação para a Ciência e Tecnologia for funding this study. We also thank Pedro Guilherme and Chiara Benvenuto for help in fieldwork. We are very grateful to Pedro Guilherme and Ana Manuel Costa for help in the database analysis and to Paula Afonso for the language editing. The authors thank 4 anonymous reviewers for their insightful comments on earlier drafts of this manuscript.

\section{Disclosure statement}

No potential conflict of interest was reported by the author(s).

\section{Funding}

This study was funded by the former Instituto Nacional da Água (Contrato INAG Instituto da Água-Universidade de Évora, 1996-2000), now Agência Portuguesa do Ambiente, and by Fundação para a Ciência e Tecnologia through a Grant (1996-2000) to M. Ilhéu.

\section{References}

[ARHA] Administração da Região Hidrográfica do Alentejo. 2015. Plano de Gestão da Região Hidrográfica do Guadiana (RH7) [River basin management plan of Guadiana (RH7)]. Lisboa (Portugal): Ministério da Agricultura, Mar, Ambiente e Ordenamento do Território. Portuguese.

[APA] Agência Portuguesa do Ambiente. 2019. Atlas digital do ambiente [Digital atlas of the environment]; [accessed 27 October 27 2019]. https://sniamb.apambiente.pt/. Portuguese.

Angermeier PL, Winston MR. 1998. Local vs. regional influences on local diversity in stream fish communities of Virginia. Ecology. 79:911-927.

Arthington AH. 1991. Ecological and genetic impacts of introduced and translocated freshwater fishes in Australia. Can J Fish Aquat Sci. 48(suppl 1):33-43.

Arthington AH, Bernardo JM, Ilhéu M. 2014. Temporary rivers: linking ecohydrology, ecological quality and reconciliation ecology. River Res Appl. 30:1209-1215.

Bêche LA, McElravy EP, Resh VH. 2006. Long-term seasonal variation in the biological traits of benthic-macroinvertebrates in two Mediterranean-climate streams in California, U.S.A.. Freshwater Biol. 51:56-75.

Bernardo JM, Alves MH. 1999. New perspectives for ecological flow determination in semi-arid regions: a preliminary approach. Regul Rivers: Res Manage. 15:221-229.

Bernardo JM, Ilhéu M, Matono P, Costa AM. 2003. Interannual variation of fish assemblage structure in a Mediterranean river: implications of streamflow on the dominance of native or exotic species. River Res Appl. 19:521-532.

Borcard D, Legendre P, Drapeau P. 1992. Partialling out the spatial component of ecological variation. Ecology. 73:1045-1055.

Buffington JM, Lisle TE, Woodsmith RD, Hilton S. 2002. Controls on the size and occurrence of pools in coarsegrained forest rivers. River Res Appl. 18:507-531.

Cabral MJ, Almeida J, Raposo de Almeida P, Dellinger TR, Ferrand de Almeida N, Oliveira M, Palmeirim JM, Queiroz AI, Rogado L, Santos-Reis M. 2005. Livro Vermelho dos Vertebrados de Portugal [Red Book of 
vertebrates of Portugal]. Lisboa (Portugal): Instituto da Conservação da Natureza. Portuguese.

Capone TA, Kushlan JA. 1991. Fish community structure in dry-season stream pools. Ecology. 72:983-992.

Capra H, Plichard L, Bergé J, Pella H, Ovidio M, McNeil E, Lamouroux N. 2017. Fish habitat selection in a large hydropeaking river: strong individual and temporal variations revealed by telemetry. Sci Total Environ. 578:109-120.

Castelberry DT, Cech JJ Jr. 1986. Physiological responses of native and introduced desert fishes to environmental stressors. Ecology. 67:912-918.

Cid N, Bonada N, Carlson SM, Grantham TE, Gasith A, Resh VH. 2017. High variability is a defining component of Mediterranean-climate rivers and their biota. Water (Basel). 9:1-24.

Clesceri LS, Greenberg AE, Eaton AD. 1998. Standard methods for the examination of water and wastewater. 20th ed. Washington (DC): American Public Health Association, American Water Works Association, Water Environmental Federation.

Closs GP, Lake PS. 1996. Drought, differential mortality and the coexistence of a native and an introduced fish species in a south east Australian intermittent stream. Environ Biol Fishes. 47:17-26.

Datry T, Bonda N, Boulton AJ, editors. 2017. Intermittent rivers and ephemeral streams: ecology and management. 1st ed. London (UK): Academic Press.

Datry T, Larned ST, Tockner K. 2014. Intermittent rivers: a challenge for freshwater ecology. BioScience. 64:229-235.

Datry T, Pella H, Leigh C, Bonada N, Hugueny B. 2016. A landscape approach to advance intermittent river ecology. Freshwater Biol. 61:1200-1213.

Dekar MP, Magoulick DD. 2007. Factors affecting fish assemblage structure during seasonal stream drying. Ecol Freshw Fish. 16:335-342.

Directive 2000/60/EC. 2000. Directive 2000/60/EC of the European Parliament and of the Council. Establishing a framework for Community action in the field of water policy. OJ L 327, 22.12.2000; p. 1-73.

Döll P, Schmied HM. 2012. How is the impact of climate change on river flow regimes related to the impact on mean annual runoff? A global-scale analysis. Environ Res Lett. 7:14-37.

Dufrêne M, Legendre P. 1997. Species assemblages and indicator species: the need for a flexible asymmetrical approach. Ecol Monograph. 67:345-366.

Frissell, CA, Liss WJ, Warren CE. 1986. A hierarchical framework for stream habitat classification: viewing streams in a watershed context. Environ Manage. 10:199-214.

Giller PS, Malmqvist B. 1998. The biology of streams and rivers. New York (NY): Oxford University Press.

Godsey SE, Kirchner JW. 2014. Dynamic, discontinuous stream networks: hydrologically driven variations in active drainage density, flowing channels and stream order. Hydrol Process. 28:5791-5803.

Harvey BC, Stewart AJ. 1991. Fish size and habitat depth relationships in headwater streams. Oecologia. 87:336-342.

Harvey BC, White JL. 2017. Axes of fear for stream fish: water depth and distance to cover. Environ Biol Fishes. 100:565573.
Humphries P, Baldwin DS. 2003. Drought and aquatic ecosystems: an introduction. Freshwater Biol. 48:1141-1146.

Ilhéu M. 2004. Padrões de Uso de Habitat da Ictiofauna em Rios de Tipo Mediterrânico [Patterns of habitat use of fishfauna in Mediterraean type rivers] [dissertation]. Évora, Portugal: Universidade de Évora. Portuguese.

Ilhéu M, Matono P, Bernardo JM. 2014. Invasibility of Mediterranean-climate rivers by non-native fish: the importance of environmental drivers and human pressures. PLoS One. 9(11):e109694.

Kershner JL, Snider WM. 1992. Importance of a habitat level classification system to design instream flow studies. In: Boon PJ, Calow P, Petts GE, editors. River conservation and management, Chichester (UK): Wiley; p. 179-193.

Labbe TR, Fausch KD. 2000. Dynamics of intermittent stream habitat regulate persistence of a threatened fish at multiple scales. Ecol Appl. 10:1774-1791.

Lake PS. 2003. Ecological effects of perturbation by drought in flowing waters. Freshwater Biol. 48:1161-1172.

Lake PS. 2011. Drought and aquatic ecosystems: effects and responses. Chichester (UK): Wiley-Blackwell; p. 100-133.

Larned ST, Datry T, Arscott DB, Tockner K. 2010. Emerging concepts in temporary-river ecology. Freshwater Biol. 55:717-738.

Leftwich K, Angermeier PL, Dolloff CA. 1997. Factors influencing behavior and transferability of habitat models for a benthic stream fish. T Am Fish Soc. 126:725734.

Legendre P. 1999. K-means partitioning program. Département de Sciences Biologiques. Montreal (ON): Université de Montreal.

Leibold MA, Holyoak M, Mouquet N, Amarasekare P, Chase JM, Hoopes MF, Holt RD, Shurin JB, Law R, Tilman D, et al. 2004. The metacommunity concept: a framework for multi-scale community ecology. Ecol Lett. 7:601-613.

Leigh C, Boulton AJ, Courtwright JL, Fritz K, May CL, Walker RH, Datry T. 2016. Ecological research and management of intermittent rivers: an historical review and future directions. Freshwater Biol. 61:1181-1199.

MacArthur RH, Wilson EO. 1967. The Theory of Island Biogeography. Princeton (NJ): Princeton Univ Press.

Magoulick DD. 2000. Spatial and temporal variation in fish assemblages of drying stream pools: the role of abiotic factors. Aquat Ecol. 34:29-41.

Magoulick DD, Kobza RM. 2003. The role of refugia for fishes during drought: a review and synthesis. Freshwater Biol. 48:1186-1198.

Matono P, Batista T, Sampaio E, Ilhéu M. 2019. Effects of agricultural land use on the ecohydrology of small-medium Mediterranean river basins: insights from a case study in the south of Portugal. In: Loures L, editor. Land useassessing the past, envisioning the future. IntechOpen eBook; p. 29-51.

Matono P, Bernardo JM, Oberdorff T, Ilhéu M. 2012. Effects of natural hydrological variability on fish assemblages in small Mediterranean streams: implications for ecological assessment. Ecol Indic. 23:467-481.

Matono P, Bernardo JM, Costa AM, Ilhéu M. 2014. Fish response to anthropogenic pressures in temporary streams: the importance of environmental drivers. River Res Appl. 30:1281-1295. 
Matono P, da Silva J, Ilhéu M. 2018. How does an invasive cyprinid can benefit from the hydrological disturbance of Mediterranean temporary streams? Diversity (Basel). 10:47.

Matono P, Sousa D, Ilhéu M. 2013. Effects of land use intensification on fish assemblages in Mediterranean climate streams. Environ Manage. 52:1213-1229.

Matthews WJ. 1986. Fish faunal "breaks" and stream order in the eastern and central United States. Environ Biol Fishes. $17: 81-92$

Matthews WJ. 1998. Patterns in freshwater fish ecology. New York (NY): Chapman \& Hall.

Matthews WJ, Marsh-Matthews E. 2003. Effects of drought on fish across axes of space, time and ecological complexity. Freshwater Biol. 48:1232-1253.

Meffe GK. 1984. Effects of abiotic disturbance on coexistence of predator-prey fish species. Ecology. 65:1525-1534.

Minckley WL. 1973. Fishes of Arizona. Phoenix (AZ): Arizona Game and Fish Department.

Minckley WL. 1983. Status of the razorback sucker, Xyrauchen texanus (Abbott), in the Lower Colorado River system. Southwestern Nat. 28:1165-1187.

Miranda P, Coelho FS, Tomé AR, Valente MA. 2002. 20th century Portuguese climate and climate scenarios. In: Santos F, Forbes K, Moniz R, editors. Climate change in Portugal: scenarios, impacts and adaptation measuresSIAM Project. Lisboa (Portugal): Gradiva; p. 23-84.

Mundahl ND. 1990. Heat death of fish in shrinking stream pools. Am Midl Nat. 123:40-46.

Pianka ER. 1970. On r- and K-selection. Am Nat. 104:592-597.

Pires DF, Beja P, Magalhães MF. 2014. Out of pools: movement patterns of Mediterranean stream fish in relation to dry season refugia. River Res Applic. 30:1269-1280.

Power ME. 1984. Depth distributions of armored catfish: predator-induced resource avoidance? Ecology. 65:523-528.

Power ME. 1987. Predator avoidance by grazing fishes in temperate and tropical streams: importance of stream depth and prey size. In: Kerfoot WC, Sih A, editors. Predation: direct and indirect impacts on aquatic communities. Dartmouth (NH): University Press of New England; p. 333-351.

Reyjold Y, Hugueny B, Pont D, Bianco PG, Beier U, Caiola N, Casals F, Cowx I, Economou A, Ferreira MT, et al. 2007. Patterns in species richness and endemism of European freshwater fish. Global Ecol Biogeogr. 16:65-75.

Ricklefts RE, Schluter D. 1993. Species diversity in ecological communities: historical and geographical perspectives. Chicago (IL): University of Chicago Press.

Rodriguez MA, Magnan P. 1995. Applications of multivariate analysis in studies of the organization and structure of fish and macroinvertebrate communities. Aquat Sci. 57:199-216.

Schaefer JF, Marsh-Matthews E, Spooner DE. 2003. Effects of barriers and thermal refugia on local movement of the threatened leopard darter, Percina pantherina. Environ Biol Fishes. 66:391-400.

Schlosser IJ. 1982. Fish community structure and function along two habitat gradients in a headwater stream. Ecol Monogr. 52:395-414.

Schlosser IJ. 1987. The role of predation in age- and sizerelated habitat use by stream fishes. Ecology. 68:651-659.

Schlosser IJ. 1988. Predation risk and habitat selection by two size classes of a stream cyprinid: experimental test of a hypothesis. Oikos. 52:36-40.

Schwartz SS, Jenkins DG. 2000. Temporary aquatic habitats: constraints and opportunities. Aquat Ecol. 34:3-8.

Shannon CE, Weaver W. 1949. The mathematical theory of communication. Urbana (IL): University of Illinois Press.

Smith KG, Darwall WRT. 2006. The status and distribution of freshwater fish endemic to the Mediterranean basin. IUCN Freshwater Biodiversity Assessment programme. Gland (Switzerlant) and Cambridge (UK): IUCN.

Sokal RR, Rohlf FJ. 1995. Biometry. 3rd ed. New York (NY): W.H. Freeman.

Strahler A. 1952. Dynamic basis of geomorphology. Geol Soc Am Bull. 63:923-938.

Stubbington R, Chadd R, Cid N, Csabai Z, Miliša M, Morais M, Munné A, Pařil P, Pešić V, Tziortzis I, et al. 2018. Biomonitoring of intermittent rivers and ephemeral streams in Europe: current practice and priorities to enhance ecological status assessments. Sci Total Environ. 618:1096-1113.

Taylor CM. 1997. Fish species richness and incidence patterns in isolated and connected stream pools: effects of pool volume and spatial position. Oecologia. 110:560-566.

Ter Braak CJF. 1990. CANOCO version 3.1. Update notes. Wageningen (Netherlands): Agricultural Mathematics Group.

Ter Braak CJF, Smilauer P. 1998. CANOCO reference manual and user's guide to CANOCO for Windows. Ithaca (NY): Microcomputer Power.

Torgersen CE, Price DM, Li HW, McIntosh BA. 1999. Multiscale thermal refugia and stream habitat associations of chinook salmon in Northeastern Oregon. Ecol App. 9:301-319.

Tramer JE. 1977. Catastrophic mortality of stream fishes trapped in shrinking pools. Am Midl Nat. 97:469-478.

Vörösmarty CJ, McInyre PB, Gessner MO, Dudgeon D, Prusevich A, Green P, Glidden S, Bunn SE, Sullivan CA, Liermann CR, et al. 2010. Global threats to human water security and river biodiversity. Nature. 467:555-561.

White RSA, McHugh PA, McIntosh AR. 2016. Drought survival is a threshold function of habitat size and population density in a fish metapopulation. Global Change Biol. 22:3341-3348.

Winemiller KO, Rose KA. 1992. Patterns of life history diversification in North American fishes: implications for population regulation. Can J Aquat Sci. 49:2196-2218. 